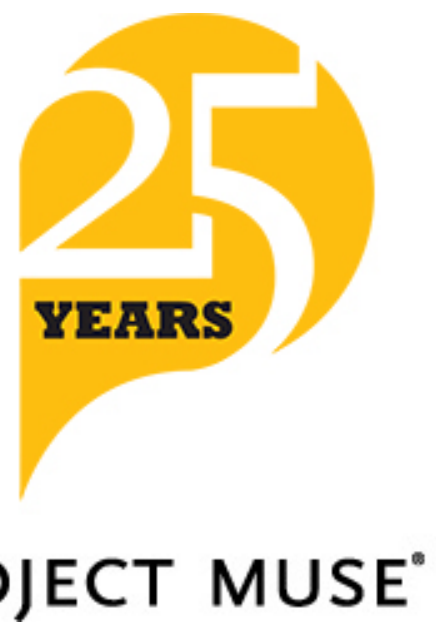

Music at the Close: Richard II in the Elizabethan

Anthologies

Ted Tregear

Studies in Philology, Volume 116, Number 4, Fall 2019, pp. 696-727 (Article)

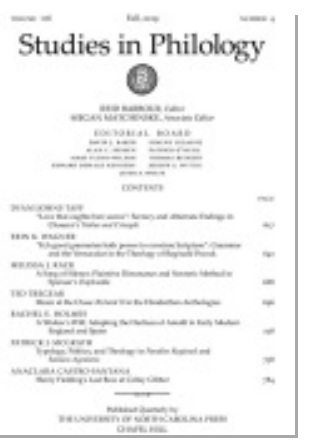

Published by The University of North Carolina Press

DOI: https://doi.org/10.1353/sip.2019.0028

$\Rightarrow$ For additional information about this article https://muse.jhu.edu/article/734420 


\title{
Music at the Close: Richard II in the Elizabethan Anthologies
}

\author{
by Ted Tregear
}

The dying words spoken by John of Gaunt have a long afterlife: as sententious lines bound to catch the eye of a commonplacing reader, they seem almost designed to appear outside their dramatic setting, in manuscript and printed compilations. This essay reads Gaunt's deathbed scene, in William Shakespeare's Richard II 2.1, in the light of two anthologies printed in 1600, Englands Parnassus and Belvedere, both derived in some way from the circle of printers and editors surrounding John Bodenham. Richard II's strong representation in both volumes testifies to its wider popularity, and that popularity was doubtless aided in turn by these anthologies. Beyond that, though, this moment of the play seems peculiarly anthologizable. Words spoken on the point of death were frequently thought to acquire a special truthfulness, even a sense of prophecy. Through an examination of dying moments in a variety of early modern sources, from Michel de Montaigne to Antonio Minturno, this essay is an experiment in thinking about how William Shakespeare might have shaped his plays for a commonplace-book culture. It looks closely at the unexpectedly lyrical quality of the sententiae themselves and the intimate relationship between lyric and sententiae in the play and the anthologies. It reads Gaunt's famous encomium to "this sceptred Ile" as it appears when read through the anthologies' negotiation of poetry and nationhood. And it considers the affinity between the peculiar life of the "choicest flowers" gathered in these anthologies, and the dying words they choose.

J

OHN of Gaunt is waiting on his deathbed for the arrival of his nephew, the capricious young king whose decline and death are the subject of William Shakespeare's Richard II. "Wil the King come," he frets, "that I may breathe my last? / In holsome counsell to his vnstaied youth." ${ }^{1}$ On the evidence of Richard's prior conduct, Gaunt's compan-

1 Shakespeare, Richard II, in The New Oxford Shakespeare: Critical Reference Edition, ed. Gary Taylor, John Jowett, Terri Bourus, and Gabriel Egan, 2 vols. (Oxford: Oxford Univer-

696

(C) 2019 Studies in Philology, Incorporated 
ion, the Duke of York, is doubtful: "all in vaine comes counsell to his eare" (2.1.4). But if ever this most absolute of monarchs could be made to listen to counsel, this would be the moment:

Oh but they say, the tongues of dying men,

Inforce attention like deepe harmony:

Where words are scarce they are seldome spent in vaine,

For they breathe truth that breathe their wordes in paine:

He that no more must say, is listened more

Than they whom youth and ease haue taught to glose,

More are mens ends markt than their liues before:

The setting Sunne, and Musike at the close,

As the last taste of sweetes is sweetest last,

Writ in remembrance more than things long past[.]

$$
\text { (2.1.5-14) }
$$

Against York's skepticism, John of Gaunt summons the authority of a proverb: the last words of dying men, "they say," are invested with a peculiar sort of power by virtue of the occasion on which they are spoken. This scene might prove a new beginning for Richard, however dissolute his career so far. Gaunt is improvising variations on the proverbial idea, familiar in early modern England, that "dying men speak true." ${ }^{2}$ It is unsurprising, then, that the memory of Gaunt's words does indeed abide long, if not for Richard, then for those other observers of his deathbed scene, the audiences of the play itself. These lines occur in a range of early printed and manuscript sources. Edward Pudsey, avid watcher and reader of plays, distilled the salient point, "The tongues of Dying men / Enforce attention"; so did a seventeenth-century Scottish reader, rewording the same thought in the margin of his first folio, "The words of dieing men of weght to persuade." An Oxford student copied out the whole passage sometime in the decade following Shakespeare's death. ${ }^{3}$ And Gaunt's dying words appeared in print, extracted

sity Press, 2017), 2.1.1-2. All subsequent quotations of Shakespeare's plays and poems are from this edition and will be cited parenthetically within the text by act, scene, and line.

2 Morris Palmer Tilley, A Dictionary of the Proverbs in England in the Sixteenth and Seventeenth Centuries (Ann Arbor: University of Michigan Press, 1950), M514.

${ }^{3}$ For Pudsey, see Shakespeare Birthplace Trust Record Office, ER 82/1/21, f.1, transcribed on DEx: A Database of Dramatic Extracts (https://dex.citd.tamu.edu). For the Meisei First Folio (MR 774), see Akihiro Yamada, ed., The First Folio of Shakespeare: A Transcript of Contemporary Marginalia in a Copy of the Kodama Memorial Library of Meisei University (Tokyo: Yushodo Press, 1998), 107. For the Oxford student, see Bodleian Library MS Eng. misc. d.28, discussed in Guillaume Coatalen, "Shakespeare and other 'Tragicall Discourses' in an Early-Seventeenth-Century Commonplace Book from Oriel College, Oxford," English Manuscript Studies, 1100-1700 13 (2007): 120-64. For manuscript 
from their setting, in two anthologies published in 160o: Englands Parnassus and Bel-vedére or the Garden of the Muses. Shakespeare's lines are arranged in these volumes alongside excerpts on similar themes by his illustrious predecessors and contemporaries, gathered to form what Englands Parnassus calls "The choysest flowers of our Moderne Poets."

Early readers seem to obey the self-fulfilling logic of Gaunt's proverb. These, after all, are dying words about dying words. Their proverbial ring lends Gaunt's argument an authoritative force through the consensus it implies; and they in turn are invested with a special authority by coming from the mouth of a character who will shortly die. Worthy though Gaunt's idea may be in itself, its worth is augmented by its setting and its speaker. What makes his words especially extractable is the context from which they are extracted. The consequences of this paradox, for the poetry and the drama of the play, are the subject of this essay, which sets out to read Richard II in the light of what feel like its most extractable moments. For even without the commonplacemarkers that often underscored a play's most gnomic moments, these lines are marked as the sort of lines readers should extract by the impersonal "they say." 4 This expression belongs among the class of phrases Desiderius Erasmus recommends, to readers of his 1508 Adages, as signalling "an advance correction of what seems excessive," proepiplēttein tềi hyperbolèi. "Similarly we should 'make an advance correction' of the proverb," he advises, "and, as it were, go halfway to meet it, if it is likely to prove obscure, or to jar in some other way." ${ }^{5}$ Erasmus's "advance correction" - the Greek expression is borrowed from Quintilian-works to parry accusations of pretension that recherché proverbs might elicit, but it is equally a gesture of easy familiarity with the classical world and an invitation to future readers to join a time-honored community of speakers. "They say" is a kind of deictic, catching the reader's attention and turning it toward the following proverb. Commonplacing readers can follow where it points before discarding it, keeping only the prov-

excerpts from Shakespeare and other dramatists, a subject beyond this essay's scope, see Laura Estill, Dramatic Extracts in Seventeenth-Century English Manuscripts: Watching, Reading, Changing Plays (Newark: University of Delaware Press, 2015).

4 For commonplace-markers see, among others, G. K. Hunter, "The Marking of Sententiae in Elizabethan Printed Plays, Poems, and Romances," Library s5-6 (1951): 171-88; Margreta de Grazia, "Shakespeare in Quotation Marks," in The Appropriation of Shakespeare: Post-Renaissance Reconstructions of the Works and the Myth, ed. Jean I. Marsden (Hemel Hempstead: Harvester Wheatsheaf, 1991), 57-71; and Adam G. Hooks, "Necessary Quotation Marks," www.adamghooks.net.

${ }^{5}$ Erasmus, Collected Works of Erasmus (CWE), vol. 31, Adages Ii1 to Iv1oo, trans. Margaret Mann Phillips (Toronto: University of Toronto Press, 1982), 28. 
erb itself: "the tongues of dying men / Inforce attention." What remains, conveniently, is a regular pentameter ripe for commonplacing.

This is how it appears in Belvedere, which restricts itself to shorter quotations only, "each line being a seuerall sentence, and none exceeding two lines at the vttermost." ${ }^{\prime}$ Readers looking for poetic lines to work into their own lives can turn to the appropriate subject heading - from "God" at one end to "Death" at the other-to find any number of useful sentiments. Gaunt's speech is accordingly disarticulated, with each of its variations entered under a separate commonplace heading:

i. The tongues of dying men enforce attention.

ii. Where words be scarse, th'are seldome spent in vaine, / For they speake truth, that breath their words with paine.

("Of the Tongue, \&c.")

iii. He that no more must speake, is listned more, / Than they whome youth and ease hath taught to glose.

("Of Paine")

iv. More are mens ends markt, than their liues before. ("Of Life") ${ }^{7}$

By providing so rich a seam of material, this speech presents too a paradoxical challenge of organization. Were there a single extractable sentence, the compiler's job would be easier; but as a quick succession of sententiae, the speech stands out in toto to the commonplacing reader. In Englands Parnassus, it appears as a whole, under the heading of "Death." The anthology's editor Robert Allot, a minor figure on the London literary scene, begins mid-line with "-The toongs of dying men." But because the protractedly sententious feel of these lines suits the anthologist's purpose, the passage is allowed to run, right up to the end of line 14: "Writ in remembrance more, then things long past." ${ }^{8}$ Allot seems to linger on Gaunt's words, finding over every line-break another sentence to extract. Sententiae are by definition closed units, beginning and ending at themselves; this elegant concision is partly what allows them to slip into any social occasion, while retaining what Erasmus calls their "shrewd and novel turn." ${ }^{9}$ Here, though, the sententiousness of each line attracts a contrary attention to how those lines relate to one another. The detachability of the speech's parts binds them closer together and reveals through the desirability of their commonplaceable content their coherence of form. What emerges is the unexpectedly musical strain of Gaunt's speech. His listeners are caught by the "deepe harmony" of

6 Bel-vedére or the Garden of the Muses (London, 160o), A3v; the title is generally modernized, as in its subsequent uses here, to Belvedere.

7 Belvedere, M6r, O7r, M6r, and Q2r.

8 Englands Parnassus: or The choysest Flowers of our Moderne Poets (London, 160o), E3v.

9 Erasmus, CWE, 31:4. 
his dying words-their sound, as much as their soundness. It is not the words of dying men, exactly, but their "tongues" that enforce attention: as though, on the verge of death, characters in Gaunt's condition acquire a certain physical and technical virtuosity. The image returns after his death in the usually unlyrical mouth of Northumberland, who announces that "His tongue is now a stringlesse instrument" (2.1.150). Elsewhere in the play, especially at moments of parting, the sensuous properties of words are similarly cherished beyond their communicative force. Bidding farewell to his native English, Mowbray laments that

my tongues vse is to me, no more

Than an vnstringed violl or a harpe,

Or like a cunning instrument casde vp,

Or being open, put into his hands

That knowes no touch to tune the harmonie[.]

(1.3.155-59)

Before Gaunt's voice is likewise encoffined, he intends to use it with all the cunning he can muster. His deathbed affords him a poignant occasion not just to articulate parting words of wisdom but to sing for himself a fitting elegiac swan song.

The music of Gaunt's speech is audible to those readers, like Allot, who linger over its commonplaces; in a time when playgoers talked of hearing plays as much as watching them, it is worth articulating what it is like to listen to these lines as a whole. ${ }^{10}$ The opening proverb works like a musical theme, repeated and developed in subsequent lines. First comes an augmented restatement in a rhymed couplet, a form so customary for the expression of general truths that the sententious and lyrical dimensions of Gaunt's speech are developed at one stroke. The following two lines open in the same vein, with polished but undaring solidity, before the expectation of rhyme is snatched away by the word "glose." Somewhere over the course of the following line, though, this experience of frustration gives way to a gradually evolving hypothesis that the rhyme has not been abandoned but suspended and developed. With its final word comes the verification that the consecutive rhyme of "vaine" and "paine" has modulated into the cross-rhyme of a quatrain. The slow crescendo of disorientation, anticipation, and eventual confirmation unfolds over the course of the speech's first single-line sententia,

More are mens ends markt than their liues before:

10 On this point, see Allison K. Deutermann, Listening for Theatrical Form in Early Modern England (Edinburgh: Edinburgh University Press, 2016). 
The attention of listening demanded by the quatrain makes the third line a decisive aural event, as the misrecognition of an unconsummated couplet gives way to the celebration of a new rhyme-pattern. Having lost its bearings, the ear is glad (in George Puttenham's words) "to heare the like tune reported, and to feele his returne."11 One of the critical pleasures of pausing on this speech lies in discovering that the musical return coincides with the meaning of the line. We may be too disoriented or too expectant to notice, but the sententia teaches us how we listen to it: it is the end of the line, not its life before, that we are waiting to mark. The terminal colon that follows seems to introduce another single line, dividing the quatrain in a 2-1-1 pattern, but as the quatrain slips into a couplet, the 3-3 form of a sixain stanza comes into view:

The setting Sunne, and Musike at the close,

As the last taste of sweetes is sweetest last,

Writ in remembrance more than things long past[.]

As the sun sets and the music approaches its "close" - the cadence of the quatrain - the line continues into a deftly economical sequel, dominated by the sound of "As . . . last taste . . . last" within which "sweetes" and "sweetest" sit nestled. Perhaps because of the protraction of this vowel sound, the word last feels present in both its senses, as the final taste and the taste that endures. After this couplet, Gaunt returns to the concrete hope with which his verse began:

Though Richard my liues counsell would not heare, My deaths sad tale may yet vndeafe his eare.

(2.1.15-16)

That the sunset, the cadence, the taste of sweetness might outlast historical record; that our attention is enforced not by the counsel, nor by its consequences, but by the poetic event itself; that the experience of Gaunt's music might be remembered longer, and better, than the events of the play, resonating even after the performance is over and the book is closed-this is what makes Gaunt's speech so daring in its claim and so overwhelming in its affect. Spoken in a slacker moment of narrative, his words nevertheless seem to hold the future trajectory of the play under their spell. Richard the sun-king grows sweet at his setting, and his last scene is accompanied by an uncanny music at the close. On the one hand, Gaunt's speech offers its readers extractable sentences from

11 Puttenham, The Arte of English Poesie, ed. Gladys Doidge Willcock and Alice Walker (Cambridge: Cambridge University Press, 1936), 76. 
the mouth of a dying man; on the other, it knits them together into a sixain stanza, framed by a couplet on either side, to form what feels like a minor lyric.

Although both 1600 anthologies prefer Shakespeare's poems to his plays, Richard II was an especially popular source for quotations, following close behind Romeo and Juliet with seven entries in Englands Parnassus and outstripping every other dramatic work in Belvedere with forty-eight. ${ }^{12}$ The play's strong representation testifies partly to its wider popularity, running to five printed editions before the 1623 folio; some of this popularity may conversely be attributed to its presence in these anthologies. Beyond this, though, Richard II is an irresistibly anthologizable play. Certain moments in it seem designed to catch the eye of a commonplacing reader, marking out extractable passageswhether isolated maxims, longer stretches of verse, or (as in this case) both - to be extracted. ${ }^{13}$ This argument runs against the grain of an influential article, published in 2008, by Zachary Lesser and Peter Stallybrass. Lesser and Stallybrass credit the circle gathered loosely around John Bodenham, from whose activities Belvedere and (more perplexingly) Englands Parnassus derive, with retrospectively making English drama respectable, both through their involvement in these and other anthologies - known as the "Wits" series - and through their markingup of printed plays with commonplace-markers and italics. ${ }^{14}$ Insofar as this authorized a concerted critical interest in playtexts, they argue, drama received its increasingly literary standing "primarily through the activity of readers, not authors, beginning with the circle of John Bodenham and widening to include a host of other readers." ${ }^{15}$ Besides the paratextual markers of commonplaces, though, there are a range of subtler cues within a text-like Erasmus's "advance correction" - which

12 Charles Crawford, ed., Englands Parnassus (Oxford: Clarendon Press, 1913), 380; Lukas Erne and Devani Singh, "Newly Discovered Shakespeare Passages in Bel-vedére or The Garden of the Muses (1600)," Shakespeare 14.4 (2018): 1-9. The forthcoming edition of Belvedere, by Lukas Erne and Devani Singh, will allow sharper judgments on this front; I am grateful to them for sharing their work in progress with me.

13 Several recent critics have approached this aspect of the play from a bibliographic perspective: see Holger Schott Syme, "'But, what euer you do, Buy': Richard II as Popular Commodity," in Richard II: New Critical Essays, ed. Jeremy Lopez (London: Routledge, 2012), 223-44; and Adam G. Hooks, Selling Shakespeare: Biography, Bibliography, and the Book Trade (Cambridge: Cambridge University Press, 2016), 66-98.

14 For the "Wits" series, see Hyder Edward Rollins, ed., England's Helicon, 2 vols. (Cambridge, MA: Harvard University Press, 1935), 2.41-63.

15 Lesser and Stallybrass, "The First Literary Hamlet and the Commonplacing of Professional Plays," Shakespeare Quarterly 59 (2008): 414. 
indicate a sentence worth extracting. However remote authors may remain from the former activity, they are intimately implicated in the latter. Commonplace-markers, after all, generally recognize commonplaces rather than creating them; sententiousness is a property of the play as well as its printing. Lesser and Stallybrass concede this point when they touch on a commonplace couplet from the 1609 Troilus and Cressida: whoever was responsible for commonplace-markers, they remark, "Shakespeare has urged them to commonplace his line." ${ }^{16}$ From this standpoint, it is easier to imagine a playwright who fashioned his plays according to the culture in which they would be read, a culture of extracting and commonplacing. ${ }^{17}$ If that culture, as manifested in these two anthologies, accorded a new respect to drama's literary qualities, then Shakespeare was as responsible as his readers, by including within his plays sententiae and other elements that offer themselves up to be anthologized.

This essay is an experiment in thinking seriously, if speculatively, about the consequences of this idea, through a close reading of a single scene from Richard II. This play, I want to suggest, is especially inflected by the culture of commonplacing, preoccupied as it and its characters are with the posthumous existence of spoken words. Reading Richard by the light of its reception, however tentatively, reveals what might be called a dramaturgy of commonplacing, according to which certain moments - what might be called "anthology moments" - are especially remarkable as sources of sententious and lyrical material. This essay will explore the paradox according to which impersonal sayings are all the more extractable when spoken by particular persons at particular times, and the unexpected relationship between character and commonplaces this paradox implies. It will develop further the dynamic between the musical and the proverbial strains of Gaunt's lyric, tracing their closeness as the scene builds to the encomium to "this sceptred Ile" of England, while returning to the related questions of sententiousness, lyric, and community already introduced. And by looking more closely at these two 1600 volumes, it will consider the affinity between the power

16 Ibid., 414-15. Tiffany Stern likewise suggests that Shakespeare "may even have shaped his plays to the commonplace-book culture" ("Watching as Reading: The Audience and Written Text in Shakespeare's Playhouse," in How To Do Things with Shakespeare: New Approaches, New Essays, ed. Laurie Maguire [Maldon, MA: Blackwell, 2008], 144).

17 See, among others, Adam Smyth, "Commonplace Book Culture: A List of Sixteen Traits," in Women and Writing, c. 1340-1650: The Domestication of Print Culture, ed. Anne Lawrence-Mathers and Phillipa Hardman (York: York Medieval Press, 2010), 90-110. 
of dying words and the peculiar half-life of choicest flowers gathered in the anthology.

As John of Gaunt knows, dying words are all the more effective for their transience, the scarcity value they seem to share with their speakers. "The last words of good men are best," wrote the seventeenth-century clergyman Thomas Adams, "as the last glimpse of the candle is the most bright: the last glare of the Sun going downe most cleare: the last speech of a deare friend parting with his friends, and departing out of the world, is usually most compassionate and patheticall."18 Their reputation for unusual trustworthiness derives from similarly pragmatic reasons, spoken as they are by people about to be freed from any worldly motives that might cause them to lie. This is the logic of the "dying declaration" in common law, by which dying words are exempted from the general ban on hearsay as evidence. As Karl Guthke notes, modern legal commentaries regularly gloss this principle with reference to Shakespeare-or, rather, to the mortally wounded Melun in King John, who with his last words warns the English nobles of the Dauphin's perfidy ${ }^{19}$ Like Gaunt's proverbial variations, these are dying words about dying words:

What in the world should make me now deceiue,

Since I must loose the vse of all deceite?

Why should I then be false, since it is true

That I must dye heere, and liue hence, by Truth?

(5.4.26-29)

That Melun is a decidedly peripheral character only strengthens the case these lines are adduced to support. Dying words are more plausible the less interest their speaker apparently has in saying them: the more anonymous the speaker, the truer the words. Lesser and Stallybrass would recognize this logic. In one of their article's confrontations with Lukas Erne, they emphasize that sententiousness, not fuller

18 Adams, A Commentary or, Exposition vpon the Divine Second Epistle Generall, written by the Blessed Apostle St. Peter (London, 1633), 206.

19 Guthke, "Last Words in Shakespeare's Plays: The Challenge to the Ars Moriendi Tradition," Jahrbuch der Deutschen Shakespeare-Gesellschaft West 1 (1992): 81. For a skeptical appraisal of Shakespeare's dying declarations, see Harriet C. Frazier, "'Like a Liar Gone to Burning Hell': Shakespeare and Dying Declarations," Comparative Drama 19 (1985): 166-80. 
and "rounder" characterization, is what made Shakespeare's plays "literary": ${ }^{20}$

Rather than demonstrating the depth of any character, lines marked as sententiae are deliberately designed to be extracted from the dramatic situation and from the character who speaks them. And they are pre-marked as extractable precisely because they testify not to individuality but to the commonplace. ... Literariness does not deepen dramatic character here, because character is not what is at stake. ${ }^{21}$

If Gaunt's lines are extractable, it is (by this argument) because they likewise say little about his character. I want to broaden my focus in this part of the essay by turning to Michel de Montaigne, and to other early modern and modern writers, to think further about the force of dying words. There is, I will suggest, a more dialectical relationship between character and commonplace than Lesser and Stallybrass assume, revealed especially in the idea that dying words reveal a truth about their speaker's character-a truth which, nevertheless, those speakers may not recognize as their own.

In King John, Melun's mind is on living as much as dying. "Here" and "hence" collapse into a single temporal moment, caught in the light of a suggestively capitalized "Truth." This truth is a positive and transcendent value, not merely the negation of lying. The deathbed marks a rite of passage to an undiscovered country whose contours can only sporadically be glimpsed in dying words; they speak, as it were, from another place, perceiving a rapidly vanishing life with sudden clarity. In one of his essays, Montaigne takes this as the true sense of Solon's famous maxim, "That we should not iudge of our happinesse, vntill after our death." What this means, he argues, is not that fortune ambushes happy lives at the last minute, but that true happiness-tranquillity of mind and resolution of soul-"should never be ascribed vnto man, vntil he have bin seene play [sic] the last act of his comedie, and without doubt the hardest." "In all the rest," he counsels, "there may be some maske":

But when that last parte of death, and of our selves comes to be acted, then no dissembling will availe, then it is high time to speake plaine English, and put off all vizardes [il n'y a plus que faindre, il faut parler François]: then whatsoever

20 See Erne, Shakespeare as Literary Dramatist, 2nd ed. (Cambridge: Cambridge University Press, 2013), 244-68.

${ }^{21}$ Lesser and Stallybrass, "First Literary Hamlet," 415-17. 
the pot containeth must be shewne, be it good or bad, foule or cleane, wine or water.

\section{Nam verae voces tum demum pectore ab imo \\ Eijiciuntur, E eripitur persona, manet res. \\ For then are sent true speeches from the heart, \\ We are our selves, wee leave to play a parte.}

Loe here, why at this last cast, all our lives other actions must be tride and touched. It is the maister day, the day that judgeth all others: it is the day, saieth an auncient Writer, that must iudge of all my forepassed yeares. To death doe I referre the essay of my studies fruite. There shall we see whether my discourse proceede from my heart, or from my mouth. ${ }^{22}$

Montaigne delightedly expands the theatrical conceit he finds in Lucretius's persona; to his description John Florio, always given to embellishing moments of theater in the Essays, adds an injunction of his own, to "put off all vizardes." ${ }^{23}$ Whether the philosopher is the supreme actor or no actor at all, however, is entirely unclear. We may "leave to play a parte" at the hour of death and yet remain enclosed within the apparatus of the theater - the last and most challenging "act," the "comedie," the "last parte of death, and of our selves." Practising death in the manner Montaigne recommends is from this latter perspective to learn one's part by heart: the timor mortis is a kind of stage fright remedied by thorough rehearsal. On this basis, one might detect the shadow of an ambiguity in Montaigne's forthright declaration that il n'y a plus que faindre: "there is no more pretending," or just possibly, "there is nothing but pretending."

Dying words may be in character, or they may give the lie to character: if this is the moment when "wee leave to play a parte," they may speak for a deeper truth than the speaker's life has previously shown. There is a curious paradox here, where what is most characteristic may sound entirely out of character. Dying words are verae voces indeed, but they are sent up from the depths of our breasts, coming as if from a foreign place. Lying just behind Montaigne's prose is the superstition folded into the idea that "dying men speak true": the sense that, poised between this world and the next, the dying acquire the power of prophecy. Gaunt lays claim to this role explicitly:

22 Montaigne, The Essayes Or Morall, Politike and Millitarie Discourses, trans. John Florio (London, 1603), 29-30; and Les Essais, ed. Jean Balsamo, Michel Magnien, and Catherine Magnien-Simonin (Paris: Gallimard, 2007), 81-82.

23 See William M. Hamlin, Montaigne's English Journey: Reading the "Essays" in Shakespeare's Day (Oxford: Oxford University Press, 2013), 35-49. 
Me thinkes I am a prophet new inspirde,

And thus expiring do foretell of him,

His rash fierce blaze of ryot cannot last:

For violent fires soone burne out themselues.

Small shoures last long, but sodaine stormes are short:

(2.1.31-35)

"Me thinkes" indicates an elevation of the poetic tone and a transformation of the drama. It prepares its audience for an event-here a linguistic event-in a transfigured mode. Eleanor Cook has observed the phrase's tendency in Shakespeare to introduce states of "heightened actual perception." "What one perceives," she writes, "may be so, or not so, or it may be in the realm of figuration where something is and is not so at once." ${ }^{24}$ By refusing firmly to choose between seeming and being, the thinking of methinks asserts an objective appearance beyond the fantasy of Gaunt's mind, without claiming to represent an actual state of affairs. Like Theseus's poetic imagination, thought retains the form of things unknown even as it acquires, at the hands of its speaker, an indefinite sort of body. Given that this realm of figuration is the common ground of poetry and prophecy, it comes as a surprise to hear instead a sequence of commonplaces: "For violent fires...." This line and its sequels are not what "Me thinkes" promises. Far from conjuring a heightened state of consciousness, they constitute notable aphorisms to be excerpted from their setting, with no apparent escalation toward the sublime. Both lines are duly included in Belvedere, filed under the heading "Of Anger \&c." 25

Critics are frequently puzzled by what connects the loftiness of Gaunt's paean to "this sceptred Ile" with the "distinctly uninspired sententiae" by which it is preceded ${ }^{26}$ Charles Forker wards off the moment's bathos by historicizing the appeal of sentences, "for which there was greater Elizabethan than current tolerance": "No comic effect is intended," he protests. ${ }^{27}$ Not just tolerated, sententiae were often welcomed by early modern audiences, and were acclaimed by theorists as a crucial technique for the tragic dramatist above all - the pillars (as Julius Caesar Scaliger writes) by which the whole of tragedy ought to be supported. ${ }^{28}$

24 Cook, Against Coercion: Games Poets Play (Stanford, CA: Stanford University Press, 1998), 240.

25 Belvedere, $\mathrm{K} 3 \mathrm{r}$.

26 Shakespeare, Richard II, ed. Anthony B. Dawson and Paul Yachnin (Oxford: Oxford University Press, 2011), 169n.

27 Shakespeare, Richard II, ed. Forker (London: Bloomsbury, 2002), $245 \mathrm{n}$.

28 "tota Tragoedia est fulcienda" (Scaliger, Poetices libri septem [Lyon, 1561], 145). 
It would be wrong, though, to conclude that the dramatic situation and the character who speaks them are therefore unimportant. In his 1564 L'arte poetica, Antonio Minturno recommends the sentence as the means by which a play thinks - using sentenze to mean something like Aristotle's dianoia-and by which it elicits its affect. ${ }^{29}$ Decorum nevertheless dictates that sentences are appropriate for some speakers more than for others. To preserve the mimetic law of verisimilitude while articulating a more general idea, the playwright must consider who speaks sententiae on stage as carefully as what those sententiae should say. Minturno turns to Aristotle's Rhetoric for confirmation that sentences "are appropriate to the aged, as well as to those who do not lack authority and are not ignorant of the affairs of which they speak sententiously. Therefore aged men are brought on the stage in order that with sayings full of reason they may commend, reprehend, admonish, comfort, and terrify." ${ }^{30}$ Anthologists looking out for sententious material know to save their attention for a particular type of character: John of Gaunt, Friar Lawrence, Polonius. Not only do sentences suit the characters of older men, Minturno suggests, but old men are often brought on stage specifically for the purpose of speaking sentences. This thought has serious dramaturgical implications. Which comes first, character or sayings? Do characters govern and determine the sentences they speak, or are they introduced merely as vehicles for sententiae? Might characters like Gaunt or Polonius have been shaped according to the wise things they say, as if they were walking commonplace books? ${ }^{31}$

Perhaps, though, the deathbed might stage a less antagonistic contest for priority between character and commonplaces. The sententiae Gaunt speaks, like verae voces from dying men, mark out the furthest boundaries of his character, where personhood at its extreme produces a contrary impersonality. It is as though the truth of character can only

29 Aristotle, Poetics, $1456 \mathrm{a} 33-\mathrm{b} 8$; dianoia is regularly translated as sententia from Francesco Robortello's 1548 commentary onward.

30 "Ma che agli attempati stieno bene i detti sentenziosi, come a coloro, a cui non manca autorita, e che non sieno ignari di quelle cose, delle quali sentenziosamente parlano.... Laonde ne' Teatri i vecchi s'introducono, che con detti ragionevoli commendino, riprendano, ammoniscano, confortino, spaventino" (Minturno, L'arte poetica [Naples, 1725], 284). Translated in Literary Criticism: Plato to Dryden, ed. Allan H. Gilbert (Detroit, MI: Wayne State University Press, 1962), 295-96; see also Aristotle, Rhetoric, 1395a3-6.

31 For some participants in the protracted dispute concerning the seriousness, or otherwise, of Polonius's precepts in Hamlet, see Josephine Waters Bennett, "Characterization in Polonius' Advice to Laertes," Shakespeare Quarterly 4 (1953): 3-9; G. K. Hunter, "Isocrates' Precepts and Polonius' Character," Shakespeare Quarterly 8 (1957): 501-6; and Doris V. Falk, "Proverbs and the Polonius Destiny," Shakespeare Quarterly 18 (1967): 23-36. 
be known from the perspective of what lies beyond it. This makes the deathbed an ambiguous and volatile extreme where character and commonplace pass over into one another. The perplexity of this extreme is also behind Montaigne's equivocation about whether the dying man is an actor. According to his essay's paradox, words most truly characteristic of their speaker may seem entirely alien: death can move us to a truth of which we were entirely unaware and which we might not recognize as ours. Dying words are invested by this reasoning with an epistemological as well as an ontological significance: how we know a character and who that character is are revealed at one stroke. "Our landes, our liues, and all are Bullingbrokes," Richard laments later in the play, "And nothing can we call our owne, but death" (3.2.147-48). The jolt of this last line's final twist comes from the scandalous notion that, far from representing a blindly absolute negativity, death might offer the truest and most determinate summary of someone's life at the moment it cancels it. This, for Bert States, constitutes the truth in the concept of "character," what saves it from efforts to banish it from the dramatic lexicon: the desire "to be rather than to be forever becoming." ${ }^{32}$ After unfolding sequentially throughout the play, a character can appear all at once at the point of death: "Existence, fraught with openness, closes in on itself." ${ }^{33}$ As Gaunt approaches his end, the distinction between the character's inwardness and the scene's exterior world begins to shimmer. His sententiae are elements of impersonal objectivity that enter into his speech, tracing out the limit of his life, as it were, from the other side.

There is something mysterious about the fact that Montaigne should articulate the deathbed's manifestation of truth in such theatrical metaphors. Dying words seem like isolated outbreaks of sincerity in the uncomfortable context of a proverbially insincere artform. ${ }^{34}$ But as the domain in which this limit can be crossed and recrossed, theater presents a crucial metaphorical resource for describing and analyzing last moments. Montaigne may have found his theatrical diction in Lucretius's persona or Cicero's De senectute; he may equally have come to it on his

32 States, "Hamlet" and the Concept of Character (Baltimore, MD: Johns Hopkins University Press, 1992), 21.

33 Ibid., 49.

34 Dying words are in this respect like epitaphs, which when staged set in play a dialectic of sincerity and insincerity. Scott L. Newstok deftly shows how Shakespeare "toys with (what is taken to be) simplistic sincerity in the realm of (what is taken to be) fundamental insincerity, producing (what is taken to be) some of the most sincere drama written in English" (Quoting Death in Early Modern England: The Poetics of Epitaphs Beyond the Tomb [Basingstoke: Palgrave Macmillan, 2009], 166-67). 
own. That the deathbed marked "the last Sceane of all the Comedie" was a commonplace idea, testifying to the crowded social spectacle of early modern death. ${ }^{35}$ Surrounded by family, friends, and neighbors, the dying lay at what one historian has called "the centre of a moral theatre." ${ }^{36}$ In reformed ars moriendi manuals, deathbed companions are exhorted to assume the duties no longer permitted to the priest, comforting the dying man, praying for him, hearing his confession; in return, the dying man must manifest a faith strong enough to confirm and strengthen onlookers in God's truth. ${ }^{37}$ The conceit also testifies to the resemblance between the life well ended and the consolations of a coherent narrative, born of what Frank Kermode identified as "a need in the moment of existence to belong, to be related to a beginning and an end." 38 The good death is perhaps above all an aesthetic event. The "maister day" to which all actions may be referred, the catastrophe that untangles the knotted epitasis in the individual's personal comedy, forms the variations of life into a retrospective coherence; in Montaigne's thought, it allows for both the fluctuations of subjective existence and the guarantee of a final significance to that existence, a standpoint from which it might be seen as a whole. Shorn of any Christian eschatology in Montaigne's essay, the hour of death offers a perspective from which individuals can judge their lives while still-only just-alive. Montaigne approaches here an idea that Walter Benjamin associates above all with the novel's transcendental solitude-that the deaths of fictional characters offer the nearest way of imagining one's own "maister day": "by virtue of the flame which consumes it," Benjamin writes, the character's death "yields us the warmth which we never draw from our own fate." 39

The moment of death reveals the intimately dialectical relationship in which character and commonplaces are engaged. Gaunt's dying commonplaces mark the detached perspective from which a subject's life can be seen in its totality; they constitute and delimit the speaker to

35 Christopher Sutton, Disce Mori. Learne to Die (London, 160o), 242.

36 David Cressy, Birth, Marriage, and Death: Ritual, Religion, and the Life-Cycle in Tudor and Stuart England (Cambridge: Cambridge University Press, 1997), 392.

37 For a selection of ars moriendi manuals from across the temporal and confessional span of early modern England, see David W. Atkinson, ed., The English "ars moriendi" (New York: Lang, 1992).

38 Kermode, The Sense of an Ending: Studies in the Theory of Fiction, rev. ed. (Oxford: Oxford University Press, 2000), 4.

39 Benjamin, "The Storyteller: Observations on the Works of Nikolai Leskov," in Illuminations, ed. Hannah Arendt, trans. Harry Zohn (London: Pimlico, 1999), 100. 
whom they seem so tenuously related. Commonplaces stand in addition at the juncture between individual and collective, where an individual's thinking pushes into the realm of common wisdom, or that common wisdom impresses itself onto an individual's thought. Drawing together the various sequential traits of their speaker, dying words draw together too the living community left behind. This is what they share with prophecy. The vacillation in Gaunt's speech from vatic announcement to sententiousness and back to the lofty encomium on England reflects the proximity of commonplaces and prophecy in Richard II; they are bound by the mutual promise that words spoken within a single life may resonate with an objectivity beyond the speaker's immediate setting, addressing other times and audiences. In this way, Gaunt's commonplaces set the scene for his ensuing vision of England. Like his national encomium, as John Baxter perceptively observes, they constitute an "appeal to truths which, spoken by Gaunt but not his unique property, demonstrates his essential connection with a community of speakers." 40 Gaunt's words stretch out past the frame of his character, past the play itself, toward different communities of speakers who hold these truths in common. The story of his death, then, seems to anticipate and rehearse the story of its later reception in the anthologies. At this moment in Richard II, detachable sentences are offered up to be written in remembrance by their hearers - and readers-long after their speaker has faded from view. Sententiae in drama afford a position apparently removed not only from their speaker, but also from the play itself, through what William Engel has described as their "cunning kind of double perspective": for early modern audiences, they "conjured into being a special space from within the dramatic spectacle that enabled them to refer beyond what they were put in place simply to signify." 41 According to this double perspective, Gaunt speaks from inside and outside the play at once, extracting himself from its immanent drama to appear as a disinterested and disembodied voice. If commonplaces, like their speakers, are already detached from the settings in which they appear, their life within the play feels less important than the afterlife they imagine. Even as they are first spoken, they tend toward the anthology.

40 Baxter, Shakespeare's Poetic Styles: Verse into Drama (London: Routledge \& Kegan Paul, 1980), 63-64.

41 Engel, Death and Drama in Renaissance England: Shades of Memory (Oxford: Oxford University Press, 2002), 44. 
If there are moments in Shakespeare's plays where the plot slows to a temporary stasis, where time is spent instead in manifestations of character or thought in process; if these dramaturgic lulls make space for speeches with little necessary connection to the thrust of the play, spoken in a more ruminative mood, and extending to a more general scope; if these are the occasions which, most extractable from their dramatic setting, offer themselves up most readily to be extracted and anthologized; then deathbed scenes, with their dwindling pulse and heightened register, are instances of what might be called the "anthology moments" of a play, moments that prove especially suited for the sort of material destined for anthologies. ${ }^{42}$ Gaunt's impending death, however, does not restrict him to only the pithiest utterances. The most prominent feature of his dying moments, on the contrary, is just how long they take. His protracted death has aroused a degree of critical impatience, and it exposes him to the charge of self-contradiction. Hearing in the lines with which this essay opened only the "facile repetition of canned wisdom," Harry Berger, Jr., comments acerbically that since Gaunt's words "are neither 'scarce' nor notably hampered by whatever pain they cost him, they must not-by his own logic-be true." ${ }^{43}$ Embarrassing at best, duplicitous at worst, Gaunt's copious eloquence threatens to undermine the memorability of his final words. His sententiae seem to abandon the lapidary wisdom of the epitaph, a genre to which they are intimately related, for the more generous measures of the elegy. An epitaph, Puttenham insists, must be "such as a man may commodiously write or engraue vpon a tombe in few verses, pithie, quicke and sententious for the passer by to peruse, and iudge vpon without any long tariaunce." When they lose their epigrammatic bite, they become "long and tedious discourses," so indulgent that (as Puttenham bitterly recounts from personal experience) a reader might be locked in the church by the sexton before finishing the poem. ${ }^{44}$

This tendency toward dilation is itself characteristic of Gaunt's habits

42 This formulation is indebted to Colin Burrow's "Montaignian Moments: Shakespeare and the Essays," in Montaigne in Transit: Essays in Honour of Ian Maclean, ed. Neil Kenny, Richard Scholar, and Wes Williams (Cambridge: Legenda, 2016), 239-52.

43 Berger, Making Trifles of Terrors: Redistributing Complicities in Shakespeare, with an introduction by Peter Erickson (Stanford, CA: Stanford University Press, 1997), 199.

44 Puttenham, Arte, 56-57. For the brevity of epitaphs, see Joshua Scodel, The English Poetic Epitaph: Commemoration and Conflict from Jonson to Wordsworth (Ithaca, NY: Cornell University Press, 1991), 50-85. 
of speech. In his Model of Poesy, William Scott chose another of Gaunt's copious episodes to illustrate the figure of amplification, which works "by heaping our words and, as it were, piling one phrase upon another of the same sense to double and redouble our blows that, by varying and reiterating, may work into the mind of the reader." 45 Just as characteristic is the way Gaunt composes poetry out of commonplaces, developing sententiae into more elaborate forms of verse. His dying speeches show how one can become the other, and their reception shows how desirable both were for anthologists. Englands Parnassus was the first collection to include what is now an immediately recognizable anthology piece:

This royall throne of Kings, this sceptred Ile,

This earth of maiestie, this seate of Mars,

This other Eden, demy Paradice,

This fortresse built by Nature for her selfe,

Against infection and the hand of warre,

This happy breede of men, this little world,

This precious stone set in the siluer sea,

Which serues it in the office of a wall,

Or as [a] moate defensiue to a house,

Against the enuie of lesse happier lands.

This blessed plot, this earth, this realme, this England,

This nurse, this teeming wombe of royall Kings,

Feard by their breed, and famous by theyr byrth,

Renowned for theyr deedes as far from home,

For christian seruice, and true chiualry,

As is the sepulchre in stubburne Iewry,

Of the worlds ransome blessed Maries sonne:

This land of such deare soules, this deere deere land,

Deare for her reputation through the world,

Is now leasde out; I dye pronouncing it,

Like to a tenement or pelting Farme.

$$
\text { (2.1.40-6o) }
$$

Among the challenges in reading Gaunt's speech is judging how much emphasis to give two contrary elements: this on the one hand and now on the other. Repetitions of this largely govern the speech's tempo, setting the pulse at which it quickens and relaxes. When the energy trails off toward the end of the first sentence, the deictic's re-entry rapidly drives the speech toward its climax in what feels like its definitive refer-

45 Scott, The Model of Poesy, ed. Gavin Alexander (Cambridge: Cambridge University Press, 2013), 66. 
ent, "this England." This gestures to the subject of Gaunt's encomium as if immediately present. But this presence is abruptly whisked away by the arrival of the verb, "Is now leasde out": England is leased, if not quite lost. When the tone of prophecy returns with the dying man's words ("I dye pronouncing it"), we hear a bitterly grubby diction of leases, tenements, and pelting farms - a reversal for which in retrospect the word deare, which binds the preceding lines together, seems ironically to have prepared. What this seems for almost twenty lines to give, now removes at the very end. At stake in this judgment is the uncomfortable way Gaunt's speech enlists its poetic enargeia in the service of its political content, a content that has won this speech its often inglorious afterlife. Admiring its heightened register risks endorsing the nationalist cause it seems to promote; resisting its politics runs the contrary risk of disregarding its formal, musical properties. This unease can result in a tendency among scholars to disregard the speech's reception by embedding it firmly within the setting of the play. ${ }^{46}$ According to this tendency, now is the speech's determining deictic: Gaunt describes an England that no longer exists, bemoaning the fiscal tricks through which all that is solid - "earth," "seate," "land" - melts into air.

The speech's fame relies on an entirely contrary reading, which forgets the turn of the verb-the guise in which it is regularly reproduced in anthologies, and where this refers more simply to a country at hand. Despite the crude purposes to which it is often put in this truncated form, this is not-or not just-a misreading. It is hard to feel, with Stephen Booth, that the speech is held breathless in suspense by the exaggerated deferral of predication. ${ }^{47}$ Those extended phrases seem complete without a verb, supported instead by the demonstrative's apostrophizing force: early texts of Richard II register this feeling by splitting the speech into sentences long before the verb arrives. ${ }^{48}$ The vacillation between presence and absence, this and now, is not merely a fact of its reception. Those two deictics exemplify what Engel calls the speech's "double perspective": the force of one cannot be used to neutralize the other. Read this way, Gaunt's speech is poetry of praise, composed in the epideictic with a closing swerve toward the vituperative. The demonstrative mode of rhetoric, Thomas Wilson reminds his readers, is used not only for distinguished individuals but for "diuerse thynges,

46 See, among others, Donald M. Friedman, "John of Gaunt and the Rhetoric of Frustration," ELH 43 (1976): 279-99.

47 Booth, "Syntax as Rhetoric in Richard II," Mosaic 10.3 (1977): 87-103.

${ }^{48} \mathrm{Q}_{1}$ and $\mathrm{Q}_{3}$ include full stops after "happier lands," $\mathrm{F}$ after "Maries sonne." 
whiche are praised, and dispraised, as menne, Countreis, Citees, Places, Beastes, Hilles, Riuers, Houses, Castles." ${ }^{49}$ His list so closely resembles the contents advertised on the title page of Englands Parnassus (see figure 1) that it is hardly surprising to find this speech included in the anthology, under the heading "Of Albion," where it runs from "This royall throne of Kings" to "stubburne Iewrie" and is mistakenly attributed to Michael Drayton. ${ }^{50}$ Unlike Belvedere, Englands Parnassus makes space for longer excerpts, especially among the "Poetical Descriptions" of its second half, many of which comprise dozens of lines. It stands as evidence that readers interested in reusable sententiae might also be looking out for more sustained pieces of poetry, and the way it accentuates the verse form of certain extracts - with an indented final couplet, for instance, of a sonnet by Sidney-manifests a practice of reading at least occasionally alert to form and content at once. ${ }^{51}$ Descriptions in the demonstrative mode, especially those as lofty as Gaunt's panegyric, recommend themselves to be anthologized as readily as isolated commonplaces. Not only the speech's form but its subject too prove strikingly appropriate for this anthology's design. As the title page's typography shows, this is not Englands Parnassus but ENGLANDS Parnassus, with "Parnassus" italicized in a far smaller font. The volumes in the "Wits" series are often taken by critics to "celebrate the birth of a national literary canon," both effect and cause of a newly emboldened vernacular literature ${ }^{52}$ If so, there is a clear affinity between the anthology's larger plan and the description of Albion it includes.

As a political project, though, Gaunt's England is not so much defined as indefined by his lyrical tone; the autonomy that allows his speech to circulate freely beyond the play's setting preserves it against too total a subordination to political ends. If Englands Parnassus is in turn a nationalist undertaking, I would suggest that the nation itself is a speculative venture. However tightly intertwined the projects of national self-assertion and the consolidation of a vernacular literature may appear, the political and aesthetic rhythms of the speech - and of the anthology - are out of time with one another. "England" looks like the prime subject of this speech, with other descriptions mere alternatives piled up for copiousness's sake, but Gaunt continues beyond it,

49 Wilson, The Arte of Rhetorique (London, 1553), B2v.

50 Englands Parnassus, Z6r.

51 Ibid., C6r.

52 Neil Rhodes, Shakespeare and the Origins of English (Oxford: Oxford University Press, 2004), 170 . 


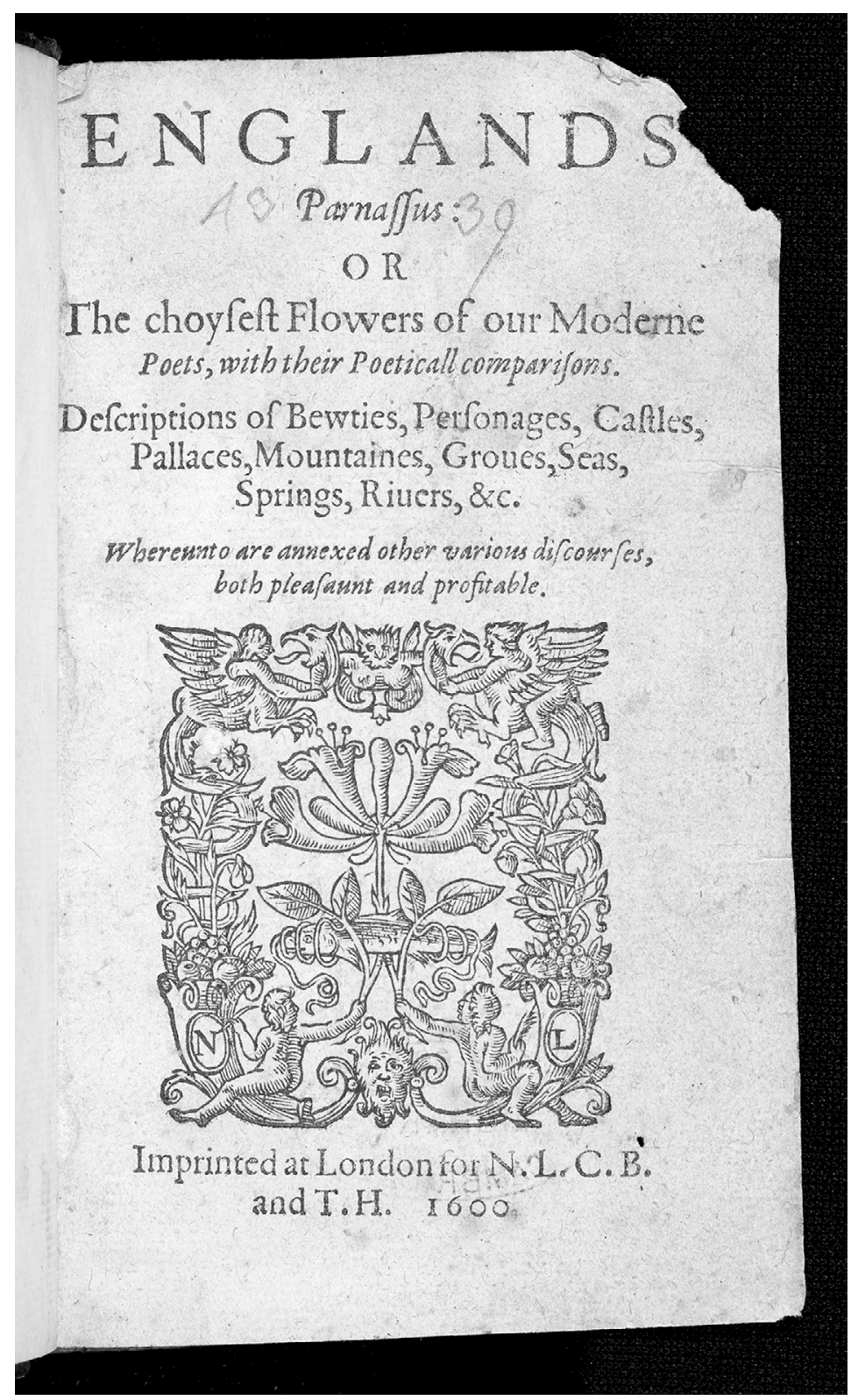

Figure 1. Englands Parnassus: or The choysest Flowers of our Moderne Poets (London, 1600), title page. With permission of the Master and Fellows of Trinity College, Cambridge. 
as if this, paired with its apparently definitive term, carries on searching for a truer object. The automatic motion of reference is for a moment interrupted, and the gap that opens up between poetic deixis and its political target places Gaunt's beloved land further out of reach the more he gestures to it. Gaunt bids farewell to an England slipping away as he speaks; but the logic of leave-taking can charge what is no longer present with the energy of what has never been, what might not even have seemed possible. At the moment of parting, the lost land is transformed into a plenipotentiary of unfulfilled and overdetermined hopes, overlaying the picture of what it was with elements of what it might be. ${ }^{33}$ This England is a hypothetical target, more golden than brazen, belonging to imagination and an unrealized future as much as to a vanishing past. With his proximal this, Gaunt indicates the closeness of this figment even as he stands far enough back to point at it from the outside. If Gaunt manifests his "essential connection with a community of speakers," as Baxter argues, then that community might also be more hypothetical than Baxter supposes. Deictics point toward what is being pointed at but also toward the subject, individual or collective, doing the pointing. Gaunt's deictics are more like what Heather Dubrow calls "convergers": demonstratives that work "with the aim of gathering in and gathering together." ${ }^{\prime 4}$ These deictics gather a composite vision of England and gather at the same time the imagined community that could recognize what their speaker sees.

The gathering that these deictics perform is partly what gives Gaunt's speech the feeling of a freestanding and autonomous lyric within Richard II. Together with its epideictic mood, regularly imported from rhetoric to classify the early modern lyric, they involve the speech in what Dubrow elsewhere calls "a gradual process of drawing together a here," a process she boldly proffers as "a characteristic-arguably the signature-of lyric." ${ }^{55}$ Two years before Englands Parnassus, in the second

\footnotetext{
53 My thoughts on leave-taking here are influenced by Theodor W. Adorno's fragmentary remarks on Beethoven, collected in Beethoven: The Philosophy of Music, ed. Rolf Tiedemann, trans. Edmund Jephcott (Cambridge: Polity Press, 1998), 162-77.

54 Dubrow, Deixis in the Early Modern Lyric: Unsettling Spatial Anchors like "Here," "This," “Come" (Basingstoke: Palgrave Macmillan, 2015), 37.

55 Dubrow, "'You may be wondering why I called you all here today': Patterns of Gathering in the Early Modern Lyric," in The Work of Form: Poetics and Materiality in Early Modern Culture, ed. Ben Burton and Elizabeth Scott-Baumann (Oxford: Oxford University Press, 2014), 38 and 24; see also the same author's The Challenges of Orpheus: Lyric Poetry and Early Modern England (Baltimore, MD: Johns Hopkins University Press, 2008), 106-55. For lyric and epideictic, see O. B. Hardison, Jr., The Enduring Monument: A Study of the Idea
} 
installment of Bodenham's "Wits" series, Francis Meres had acclaimed Shakespeare as among "the best Lyrick Poets," alongside Samuel Daniel, Michael Drayton, and Nicholas Breton. ${ }^{56}$ Meres's description might encompass Shakespeare's dramatic writing as well as his more narrowly poetic works. ${ }^{57}$ After the publication of the narrative poems, Shakespeare increasingly treated the stage as an alternative medium for the publication and reception of lyric poetry. ${ }^{58}$ The spurt of plays generally grouped by their "lyric" qualities may have been intended as a new claim for the theaters, after their reopening in 1594, as sites of lyric activity. Poems spoken onstage could be quickly extracted from their dramatic setting to function independently from their plays. If this is true most famously of the poems in Love's Labour's Lost, recited in one of that play's anthology moments and extracted for the 1599 Passionate Pilgrim, it is true also of Gaunt's speech. Instead of conjuring a single here-andnow, Gaunt's deictics act as an invitation to communal witness delivered by the play's most vatic figure. It would be wrong, then, to overstate the antagonism in Richard II between Richard's lyric effusions and Gaunt's moralistic sentiments. Those moralistic sentiments were often themselves regarded as members of the admittedly capacious category of lyric, reflecting the frequent proximity between the proverbial and the musical. William Scott, for instance, follows Scaliger in drawing together "those poesies wherein we imitate and discover our affections and moral or natural conceits, more sudden and short yet pithy and profitable, which may all be reduced under the lyric." ${ }^{59}$ Gaunt's lyric and his sententiae reach out to a community gathered together on poetic more than political grounds. It is composed according to something like

of Praise in Renaissance Literary Theory and Practice (Chapel Hill: University of North Carolina Press, 1962), 95-102.

56 Meres, Palladis Tamia (London, 1598), Oo2v-3r. For doubts concerning this volume's membership in the "Wits" series, see Celeste Turner Wright, "Anthony Mundy and the Bodenham Miscellanies," Philological Quarterly 40 (1961): 449-61.

57 It is possibly telling that, in his praise of "Honie-tong'd Shakespeare," John Weever extended his praise for Shakespeare's poetic characters to "Romea-Richard" alone from the dramatic works; though there is no telling which Richard (II or III) he means, these two conspicuously poetic protagonists - Romeo and Richard II - might merit Weever's admiration. See also Hooks, Selling Shakespeare, 8o-87.

58 See Lukas Erne, "Print and Manuscript," in The Cambridge Companion to Shakespeare's Poetry, ed. Patrick Cheney (Cambridge: Cambridge University Press, 2007), 54-71. Richard Wilson reads the play instead as a farewell to poetry's fuller affordances: "A stringless instrument': Richard II and the Defeat of Poetry," in Shakespeare's Book: Essays in Reading, Writing and Reception, ed. Richard Meek, Jane Rickard, and Wilson (Manchester: Manchester University Press, 2008), 103-19.

59 Scott, Model of Poesy, 25. 
Immanuel Kant's sensus communis, the union demanded in the name of beauty, without which beauty is unthinkable but which nevertheless remains a "mere ideal standard." 60

The proliferation of epithets before and beyond "this England" reveals a speech delighting in its own copiousness and reluctant to rein itself in for the sake of its political cause. Considering this speech as a miniature lyric emphasizes not the proximity of but the distance between its content and its form. Gaunt summons the object of his speech and its collective subject on another plane from the empirical-through the medium of poetry. This, for Jonathan Culler, is the power of apostrophe, especially in lyrics where "something once present has been lost or attenuated":

Apostrophes displace this irreversible structure by removing it from linear time and locating it in a discursive time. The temporal movement from $\mathrm{A}$ to $\mathrm{B}$, restructured by apostrophe, becomes a reversible alternation between $\mathrm{A}^{\prime}$ and $\mathrm{B}^{\prime}$; a play of presence and absence governed not by time but by poetic ingenuity or power. ${ }^{61}$

The motion of Gaunt's speech comes through this play of presence and absence-the simultaneous but contradictory this and now, the motif of farewell-as it follows the decline of its speaker. The England he praises is an image of hope saved by apostrophe's power from being betrayed to existence. However much of a victory this seems for lyric, there remains an unhappiness in its failure to fashion a world in this image. As much as lyric summons a community, it emphasizes too the imaginary quality of the principle according to which the community is summoned. If lyric calls us together, it simultaneously registers that we are blocked from answering that call, that the association with the world promised by the artwork remains unattainable. This is the irony by which a vision of life is articulated by a dying man, who cannot join the community he imagines: Gaunt's death is the condition for his insight onto the world. In a final reversal, he casts himself alone as healthy in an ailing land: "Thy death-bed is no lesser than thy land, / Wherein thou liest in reputation sicke" (2.1.95-96). Gaunt's speech is a strenuous imaginative effort-too strenuous, perhaps, for his listeners to follow. There is an inhuman aspect to it, as impersonal as the commonplaces he speaks and as detached as the deictics which, however tenderly they in-

60 Kant, Critique of Judgment, trans. Werner S. Pluhar (Indianapolis, IN: Hackett, 1987), \$22 (AA239).

61 Culler, Theory of the Lyric (Cambridge, MA: Harvard University Press, 2015), 227. 
dicate a collective life, refer to it from the outside. England is now-and for now-beyond the reach of Gaunt's this, and even further beyond his audience. Only as he is dying can Gaunt express certain elements of the life he leaves behind, while glimpsing how like death that life might look.

The life Gaunt enjoys in these twilight hours closely resembles the life of flowers chosen for the anthology. Picking a flower rescues it from death, but not for long; the metaphor's tenuity rebuffs the conceit that poems can enjoy and bestow immortality, while nevertheless imagining a life for the poem beyond its original setting. In his final exchange with Richard, Gaunt braves all threats of punishment by invoking the afterlife his words will win through his own imminent death:
Ioine with the present sicknes that I haue,
And thy vnkindnes be like crooked age,
To crop at once a too long withered flower,
Liue in thy shame, but die not shame with thee,
These words hereafter thy tormentors be,
Convay me to my bed then to my graue,
Loue they to liue that loue and honour haue.

(2.1.133-39)

The argument reprises Gaunt's protest from two scenes earlier: "Shorten my daies thou canst with sullen sorrowe, / And plucke nights from me, but not lend a morrow" (1.3.220-21). Then, the king could take but not give; now, his taking is pointless. The blow he threatens would land at the same time as age's final incision, "To crop at once a too long withered flower." When at the end of Venus and Adonis, Venus chooses not to pick but to "crop" the flower into which her love has transformed, the word erupts as an unexpected burst of violence (1175). Here, Gaunt implies a disproportionate force leveled against a pitiful target: Richard is left swinging the executioner's sword only to hasten an already impending death. Whether by force or age, Gaunt is the flower about to be picked from the stem; but this action, like the anthologist's, also grants a kind of afterlife. Once again, the drama of the scene seems to anticipate its ensuing reception. On stage is a character growing ever more indistinct, bidding farewell to the play's action with words intended to resound once he is out of mind. Those words are mortified, as it were, in advance of their speaker's death, and this wins them an easier future, 
quoted and recited in other mouths. By reproducing those words without their speaker's name, then, the anthologies of 1600 repeat the drama they seem to ignore. The "hereafter" of Gaunt's dying words stretches out beyond him and beyond their target too, promising shame and torment for Richard continuing through the chronicles of history.

When Gaunt imagines the power of his "deaths sad tale" (2.1.16), he casts himself as a dead man talking, capable of drawing the narrative of his own demise to a close. This scene offers the starkest instance of what Berger has called "the fight for the future perfect" raging throughout this play. ${ }^{62}$ Gaunt is just one of many characters to borrow the resources of the ars moriendi in order to imagine and determine his own afterlife. The aim of the ars, Berger remarks, is "to write one's own epitaph, to shape the death mask that will control the future by representing the deceased as he or she wishes to be remembered. It is an act of autobiography, of autothanatography." ${ }^{63}$ The frequency with which the play's characters find pleasure in talking "of graues, of wormes, and Epitaphs" (3.2.141) offers one explanation for Richard II's particular interest in anthology moments. For Berger, such moments are calculated illocutionary maneuvers by which characters manage their posthumous reputations; his work is devoted to chasing these anthologized speeches back into their bodies. The relationship between characters and their speeches traced by this essay, though, suggests a more thoroughgoing dramaturgy of anthology moments, according to which extractable passages are genuinely out of time with the action of the play. This question of timing is important. Lyric interrupts and reverses the course of linear time; this is true as well for the commonplace, which by definition comes from and stretches out beyond the situation in which it is produced. When spoken onstage, the commonplace detaches an event from the immanent causal nexus of the plot and presents it as an exemplification of its own eternal law. It is as if it is spoken directly to the audience, breaking through the self-enclosed action of the locus, or written above the action as a kind of caption. ${ }^{64}$ Anthology pieces are anachronistic. They interrupt the homogeneous process of time within which the historical narrative unfolds and acquire in the act a certain

62 This phrase comes from Harry Berger, Jr., Imaginary Audition: Shakespeare on Stage and Page (Berkeley: University of California Press, 1989), 104-37.

63 Ibid., 119; see also Berger, Making Trifles, 189-210.

64 See Walter Benjamin, The Origin of German Tragic Drama, trans. John Osborne (London: Verso, 1998), 196: "as its caption, the maxim declares the stage-setting to be allegorical." 
suspended feeling. The conspicuously "lyrical" tone of the whole play, one of only two written entirely in verse-the other is King John-may also register and evoke this suspended time. Samuel Taylor Coleridge even took its characters' propensity for rhyme as a reminder that "they are historical, known, and so far formal characters, the reality of which is already a fact." ${ }^{65}$ Richard II's tonal and formal consistency reflects the intensity of its thinking about the genre of the history play. Gaunt, of course, is like Talbot, or any of the characters in Shakespeare's tetralogies; each of them has "lyne," as Thomas Nashe famously wrote, "two hundred years in his Tombe." 66 As a representation of past events, the play too is structured according to the logic of the future perfect, prior to its characters' own immortal longings; through this logic, it conjures a space in which its subjects can be alive and dead at once. ${ }^{67}$

In the space that remains, though, I want to consider further the notional community that links Gaunt's commonplaces with his lyric on England. This essay has argued that Gaunt's deictics draw together something like the subjective universality famously articulated as aesthetic judgment's defining feature - a process of gathering that remains nevertheless within the realm of figuration. This might qualify the assertion that these 1600 anthologies celebrate England by means of its poets, pressing its excerpts (as it were) into national service. Their readers, I suggest, are gathered in the name of poetry rather than the nation. This is easier to argue for Englands Parnassus: the way it lingers over its excerpts, allowing them to continue and develop, even reproduces the experience Kant described when confronted by the beautiful. ${ }^{68}$ But even the sterner contents of Belvedere, restricted to two lines at the most, reveal an unexpected aesthetic aspect that binds them together more than any shared wisdom. To see this aspect, we can follow Gaunt's proverbial line, "The tongues of dying men enforce attention," into the anthology, where it is filed under the heading "Of Tongues, Words, \&c." 69 There, it appears alongside statements that corroborate, qualify, and decidedly contradict the idea that "dying men speak true." Though the

65 Coleridge, Shakespearean Criticism, ed. Thomas Middleton Raysor, 2 vols. (London: Dent, 1960), 1:132.

66 Nashe, Pierce Penilesse his Supplication to the Diuell (London, 1592), F3r.

67 Paul de Man identified this as the wishful logic of the epitaph, by which "One moves, without compromise, from death or life to life and death" ("Autobiography as Defacement," MLN 94 [1979]: 925).

68 "We linger in our contemplation of the beautiful, because this contemplation reinforces and reproduces itself" (Kant, Critique of Judgment, §12 [AA222]).

69 This heading in Belvedere runs $\mathrm{M}_{5} \mathrm{v}-\mathrm{M}_{7} \mathrm{v}$. 
sentence's inclusion appears to indicate that the anthology approves its content, Belvedere refuses to commit to the relative truths of its various extracts. One sentence entered under this heading will vouch for the sincerity of words and their possible occasions of truth, which its fellow entries will doubt. "The tongue is tell-tale of the priuat thoughts," declares the couplet in the privileged position at the opening; yet later we find a concerted preference for deeds over words: "Workes, and not words, doe most commend a man"; "The greatest words, oft times haue weakest deeds." Some entries second Gaunt's optimism: "By good perswasion, what cannot be done?" Others read his proverb to suggest that fewer words are best: "The fewer words, the more discretion"; "In many words must needs be much amisse." Each warning against too many words is ironically disabled by the frequency with which it is repeated. Words cast suspicion on each other and themselves. Repeated throughout the heading is a strong and self-doubting ambivalence about language's power. "Faire pleasing words are like to Magique Art," runs one entry, "That doth the charmed snake in slumber lay." Those pleasing words are cautiously welcomed in the lines immediately preceding: "Great power haue pleasing words, and mickle might." But the consensus finds the snake-charmer more dangerous than the snake: "In many words is couched most mistrust." The agent of such hypnotic eloquence, in this context, is Belvedere itself. By gathering its moral sentiments together, the anthology comprises a document of equivocal and seductive amorality.

Suspicion of tongues and words is itself a commonplace of early modern culture. Erasmus, master of copiousness, declared in his lengthy and bitter Lingua that the tongue is "both deadly poison and a life-giving remedy." 70 Even the proverbs found in the Adages, he cautioned, should not be overused, nor read sequentially for too long at once: "Overcrowding prevents them from letting their light shine, just as no picture catches the eye in which nothing is clear in profile."71 The perils of ignoring Erasmus's warning can be seen in Belvedere, where the moral import of any one commonplace is lost beneath a welter of competing voices. When gathered together, the contents of these sentences, for which each one was chosen, are neutralized. In this overcrowded gallery, it is hard for a reader to be struck by any one's special content, or to endorse its

70 Erasmus, Lingua, ed. and trans. Elaine Fantham, in CWE, vol. 29, Literary and Educational Writings 7 (Toronto: University of Toronto Press, 1989), 262. I am grateful to the anonymous reader from Studies in Philology for suggesting this treatise.

71 Erasmus, CWE, 31:19. 
validity. What emerges, instead, is their formal qualities. Visually, they are arranged in patterns: two self-contained lines are followed by an indented, italicized couplet, rhymed or unrhymed. Under other headings, the look of the page suggests a procession of stanzas; here, the equality of the components suggests a tonal dichotomy, with two curt sententiae (usually end-stopped) counterposed against two more expansive lines. Another of Gaunt's couplets appears in Belvedere like this:

With words and gifts, it's easie to attempt.

Speech doth preuaile, where weapons cannot win.

He that no more must speake, is listned more,

Than they whome youth and ease hath taught to glose.

All four lines meet the Bodenham criterion of "ten syllables onely"; yet the rhythms are subtly different. ${ }^{72}$ Each of the first two lines requires a certain metrical space to be left around them, as though commemorating the proverb's demand for absolute singularity noted by Erasmus: "every proverb stands by itself; and for that reason must anyway be followed by a new beginning." ${ }^{73}$ The first line could for this reason sound almost like a hexameter, with an implied beat left at the end in homage to its moral heft. The same effect is exacerbated in the second line by the following couplet's indentation, as if the eye's distended movement over blank space lengthened the pause between lines. The couplet has a different feel. The paradox of "no more ... more" might temporarily suspend the first line in a poise of its own, but the movement of "more, / Than" pushes the reader over the line break to the second, which advances with a limber and uninterrupted movement. The final couplet's looseness stands in contrast with the jerkier, more assertive quality of each preceding one-liner. Into each of those two lines is compressed the structure and timing of the more dilated couplet; the caesura at their halfway point thus bears the heavier stress of the couplet's line break. However vehement the sentiments expressed by each sententia, their collective effect is not of overwhelming moral weight. It is their apparently accidental features that come to the fore: their different rhythms, structures, repetitions, pauses, and rhymes.

Belvedere gathers sentences commendable for their moral heft and, through its presentation, draws out their aesthetic properties. In this way, it repeats the paradox observed in Gaunt's speeches at the start of this essay, where the proverbial is occluded in favor of the musical. Its

72 Belvedere, Q6r.

73 Erasmus, CWE, 31:19. 
sentences are conspicuous less for what they say than for how they say it. This reversal is just what worries so many of the sentences about their own medium: the dangerous slippage between sense and sound, between their proverbial wisdom and the deep harmony of their "Magique Art." Both anthologies, as we have seen, are often associated with an incipient national canon. But Englands Parnassus stands like Gaunt at one remove from the reality of England. The community it summons, in the running header of every opening, is the first-person plural pronoun announced on the title page: the authors collected here are "our Moderne Poets." Like this, our is a converger, calling together its modern poets, but also a group to whom they belong-as if they, like their commonplaces, were held in common. As much as it celebrates a kind of Elizabethan canon, Englands Parnassus celebrates the subjects ready to appreciate such a canon, the burgeoning community of poetry readers gathered together as our. Despite the title page's typography, England is less important than Parnassus, the term that, as Michael Gavin has recently shown, came to designate the domain of literary criticism as it emerged over the seventeenth century. ${ }^{74}$ Through its horticultural connotations, Englands Parnassus is well placed to express the lush pastoral of Gaunt's vision. But the precise site of this community is rendered uncertain by the metaphorical ambivalence in the anthology. According to its etymology, the anthology is a collection of picked flowers, selected already from wherever they first grew. The community of readers may not have a place to gather. Even Belvedere, self-proclaimed "Garden of the Muses," includes a dedicatory poem that cannot decide whether these flowers are still planted or already gathered: "Faire planted Eden of collected sweets, / Cropt from the bosome of the fertile ground."75 This anthology is, at best, a demi-paradise; the break of the line seems to mark its fall, as the flowers in the "bosome" of the ground are now-like the dying Gaunt- "Cropt." However insistently Belvedere reiterates its unfallen state, the flowers it offers may already have been picked.

Parnassus is not a place to live. Even in Belvedere's title-page device (see figure 2), the flowering ground rises to the impossibly precipitous peaks of Parnassus and Helicon, between which the sacred laurel grows. If readers are invited by these anthologies to the sacred places of poetry, they may also find that they are blocked from gathering and that their choicest flowers have begun to wither. After considering the

74 Gavin, The Invention of English Criticism, 1650-1760 (Cambridge: Cambridge University Press, 2015), 50-73.

75 Belvedere, A8r. 


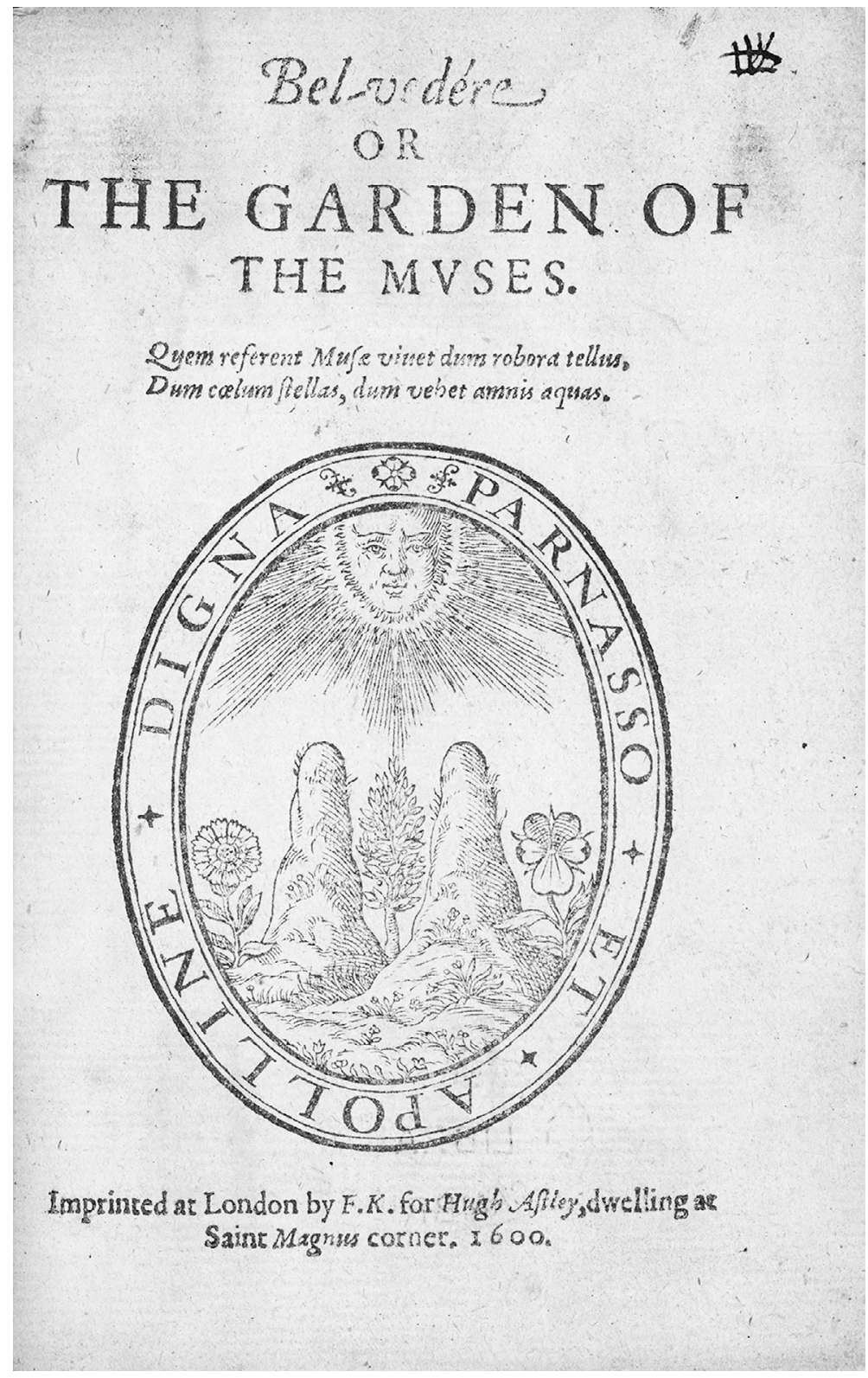

Figure 2. Bel-vedére or The Garden of the Muses (London, 1600), title page. With permission of the Master and Fellows of Trinity College, Cambridge. 
relationship between anthologies and dying words, this essay closes with the possibility that anthologies are dying words. Cropped from their sources, their excerpts seem to wither before readers' eyes, testifying not to a living poetry but to the life poetry cannot achieve. This is the conclusion Johann Gottfried Herder reached in his 1787 essay, "On Image, Poetry, and Fable." Herder bemoans the tedium of maxims, sayings, and proverbs that arise in concrete situations but survive in etiolated form in compilations. "But that is ultimately the fate of all anthologies," he continues, "whether they contain fables, songs, epigrams, maxims, and whatnot: they are scattered leaves, flowers torn from their roots which, wilting, grieve as if on their deathbed." 76 Though his evocative image is apparently disparaging, Herder perhaps felt that the transience of flowers constitutes something of their fascination. The affinity this essay has suggested between the excerpted passage and the dying man is one reason why Shakespeare is so preoccupied in this scene with questions of poetry and survival. Excerpted lines are what remain of a text after the process of reading: lines frozen, as it were, in the act of farewell. The anthology arranges them into a deathbed scene of their own, as a collection of flowers severed from their stems whose survival remains precarious. Whatever community they summon remains within the bounds of imagination, and their insight into life appears only when they leave it behind. Yet the irony of this play is that what is remembered, at least by these anthologists, are not the "things long past" belonging to the historical plot, but poetry, music, occasions in the play where characters reach beyond themselves and their settings to speak in a heavier or more elevated tone. Gathered in a collection, the flower is suspended from its natural setting, its life caught in parentheses, but only for a little time. That may still be long enough to catch sight, in these faltering moments, of another, different sort of life.

\section{Gonville and Caius College, Cambridge}

76 Herder, "On Image, Poetry, and Fable," in Selected Writings on Aesthetics, ed. and trans. Gregory Moore (Princeton, NJ: Princeton University Press, 2006), 375. 